\title{
Insiden dan Etiologi Kelumpuhan Saraf III, IV dan VI yang disertai Diplopia Binokuler di RSUD DR. Wahidin Sudiro Husodo
}

\author{
Rini Kusumawar Dhany ${ }^{1 *}$, Yunita Tanjung ${ }^{2}$, Farren Jennel ${ }^{2}$ \\ Lecturer and Ophthalmologist of dr. Wahidin Sudiro Husodo General Hospital \\ Mojokerto ${ }^{1 *}$ \\ Co-ass Medical Faculty of Wijaya Kusuma Surabaya University \\ Jalan Pahlawan 13 ${ }^{\text {th }}$, Mojokerto. East Java, Indonesia. 61322. \\ *e-mail: rininugroho@gmail.com
}

\begin{abstract}
Abstrak
Penelitian ini bertujuan untuk mengetahui insiden dan etiologi kelumpuhan saraf III, IV dan VI yang disertai diplopia binokuler di RSUD dr. Rumah Sakit Umum Wahidin Sudiro Husodo Mojokerto. Metode deskriptif dari data skunder rekam medis. Tingkat insiden disesuaikan dengan usia dan distribusi jenis kelamin populasi. Usia rata-rata onset adalah 45,6 tahun, tujuh subjek laki-laki (58,3\%) dan lima subjek perempuan (41,7\%). Kami mengidentifikasi 12 kasus diagnosis kelumpuhan saraf III, IV dan VI yang didapat selama periode 4 tahun. Penyebab paling umum dari diplopia binokular diperoleh kelumpuhan saraf keenam (33,3\%), 3 pasien mengalami kelumpuhan saraf ketiga parsial (25\%), satu pasien parese nervus ketiga pupil sparing $(8,3 \%)$, Etiologi kelumpuhan saraf diduga mikrovaskular $(58,3 \%)$ neoplasma $(16,7 \%)$, aneurisma $(8,3 \%)$ trauma $(8,3 \%)$, dan kompresi dari post neurosurgery $(8,3 \%)$. Enam pasien (50\%) dengan kelumpuhan saraf ketiga mikrovaskular memiliki diabetes mellitus, sedangkan 1 pasien $(8,3 \%)$ memiliki tingkat hipertensi grade 2 . Penyebab diplopia binokuler terbanyak adalah parese nervus VI. Faktor risiko seperti hipertensi dan diabetes mellitus yang berpengaruh signifikan dalam angka diplopia karena parese N. III, IV dan VI perlu dilakukan pemeriksaan MRI lebih awal sehingga komplikasi dan progresivitas dapat dicegah.
\end{abstract}

Kata Kunci: kelumpuhan saraf ke III, IV, VI, diplopia binokuler, neuropati mikrovaskuler

\section{Incidence and Etiologies of Third, Fourth and Sixth Nerve Palsy with Binocular Diplopia at DR. Wahidin Sudiro Husodo General Hospital}

\begin{abstract}
The purpose of this study is to determine the incidence and etiology of III, IV and VI nerve paralysis with binocular diplopia in RSUD dr. Wahidin Sudiro Husodo General Hospital Mojokerto. Method of this study was descriptive study using secondary medical record data. Incidence rates are adjusted for age and sex distribution of the population. The mean age of onset was 45.6 years, seven male subjects (58.3\%) and five female subjects (41.7\%). We identified 12 cases of acquired III, IV and VI nerve palsy over a 4-year period. The most common cause of binocular diplopia was sixth nerve palsy (33.3\%), 3 patients experienced partial third nerve palsy (25\%), one patient with third nerve palsy with pupil sparing (8.3\%). Most common etiology was microvascular (58,3\%), neoplasms (16.7\%), aneurysms (8.3\%) trauma (8.3\%), and post meningioma neurosurgery (8.3\%). Six patients (50\%) with microvascular third nerve palsy had diabetes mellitus, while 1 patient (8.3\%) had grade 2 hypertension. The most common cause of binocular diplopia was VI nerve palsy. Risk factors such as hypertension and diabetes
\end{abstract}


Insiden dan Etiologi Kelumpuhan Saraf III, IV dan VI yang disertai Diplopia Binokuler di RSUD... Rini Kusumawar Dhany, Yunita Tanjung, Farren Jennel

mellitus which have a significant effect on diplopia. Patients with N. III, IV and VI palsy need to be done early MRI examination so that complications and progression can be prevented.

Keywords: III, IV, VI nerve palsy, binocular diplopia, microvascular neuropathy

\section{PENDAHULUAN}

Pergerakan bola mata dilakukan oleh otot-otot ekstra okular yang dipersarafi oleh nervus III, IV dan VI.N. Diplopia berasal dari bahasa Latin: diplous yang berarti ganda, dan ops yang berarti mata. Anemnesis yang cermat diperlukan karena keluhan diplopia dapat muncul pada pasien dengan posisi bola mata normal atau derajat ketidaksejajaran bola mata yang sangat ringan. Diplopia dibedakan menjadi monokuler dan binokuler. Jika gejala diplopia menetap dengan satu mata ditutup, pasien mengalami diplopia monokuler dengan penyebab terbanyak adalah kelainan refraktif dan akibat obatobatan. Jika gejala diplopia hilang setelah satu mata ditutup, dinamakan diplopia binokuler, dan paling banyak disebabkan oleh kasus neurooftalmologi atau neurologi (Sreedhan and Meron, 2019; Ilyas, 2009; Dinkin, 2019).

Penyebab diplopia binokuler terbanyak adalah kelumpuhan saraf kranial terutama nervus $\mathrm{VI}$, penyebab lainnya adalah strabismus. Sebanyak 39\% penyebab diplopia binokuler adalah karena kelainan infranuklear dan sekitar 26\% disebabkan oleh kelainan mekanik otot dan trauma. Dari seluruh keluhan diplopia, 75\% adalah diplopia binokular dan 25\% adalah diplopia monokular. Mengingat hanya sepertiga pasien diplopia binokuler yang mengalami resolusi spontan, dan separuh kasusnya tidak didapatkan hasil yang baik setelah pengobatan, maka penting untuk mengetahui insiden dan etiologi untuk tindakan preventif (Merino et al, 2017).

Anamnesa untuk mengidentifikasi apakah diplopia horisontal, vertikal, atau oblik. Diplopia horizontal berhubungan dengan gangguan kontrol saraf atau fungsi otot rektus medial, otot rektus lateral, atau keduanya. Sebagai contoh, parese saraf troklear kiri menyebabkan diplopia pada pandangan ke kanan dan bawah. Onset terjadinya diplopia yang mendadak hampir selalu disebabkan oleh vaskular. Diplopia yang berlangsung perlahan dihubungkan dengan lesi kompresi. Diplopia intermiten berhubungan dengan ptosis gangguan neuromuscular seperti miastenia gravis (Sreedhan and Meron, 2019; Ilyas, 2009; Dinkin, 2019).

\section{METODE}

Jenis penelitian ini adalah penelitian deskriptif yang menggunakan data 
ISSN 1978-2071 (Print); ISSN 2580-5967 (Online) Jurnal IImiah Kedokteran Wijaya Kusuma 8(2) : 1-6, September 2019

sekunder. Data diambil dari rekam medik pasien di Poliklinik Mata Rumah Sakit Dr. Wahidin Sudiro Husodo dari Januari 2014 Juli 2018. Sampling data dengan teknik total sampling. Penelitian ini telah disetujui oleh KEPK komite etik penelitian kesehatan RSU Dr. Wahidin Sudiro Husodo No 56
/KEPK-RSWH/ EA//2019. Kriteria pasien yang menjadi sampel adalah pasien dengan keluhan diplopia binokuler karena parese $\mathrm{N}$ III, IV dan VI. Keseluruhan total sampel sebanyak 12 orang, laki-laki sebanyak 7 orang dan wanita 5 orang dengan usia dari 20-63 tahun.

\section{HASIL}

Tabel 1. Persentase Penyebab Diplopia Binokuler di RSUD Dr. Wahidin Sudiro Husodo Poliklinik Mata periode Januari 2014 - Juli 2018.

\begin{tabular}{clcr}
\hline No & Diagnosis & Jumlah & $\%$ \\
\hline 1 & Parese N III parsial & 3 & 25 \\
2 & Parese N III pupil sparing & 1 & 8,3 \\
3 & Parese N III total & 2 & 16,7 \\
4 & Parese N IV & - & - \\
5 & Parese N VI & 4 & 33,3 \\
6 & Parese N III,IV,VI gabungan & 2 & 16,7 \\
\hline & TOTAL & 12 & 100 \\
\hline
\end{tabular}

Hasil penelitian seperti pada Tabel 1 menunjukkan penyebab terbanyak diplopia binokuler adalah parese nervus VI sebanyak 33,3\%, parese nervus III parsial
$25 \%$, parese nervus III total $16,7 \%$, parese nervus III pupil sparing $8,3 \%$ dan parese nervus III, IV, VI gabungan $16,7 \%$

Tabel 2. Etiologi Parese Nervus III, IV dan VI di RSUD Dr. Wahidin Sudiro Husodo Poliklinik Mata periode Januari 2014 - Juli 2018.

\begin{tabular}{cllc}
\hline No & Nama & Etiologi & Usia \\
\hline 1 & Tn. S & Trauma (Cedera Otak Sedang) & 20 \\
2 & Tn. M & Mikrovaskular & 45 \\
3 & Tn. K & Mikrovaskular & 56 \\
4 & Ny.S & Neoplasma intrakranial & 53 \\
5 & Nn.N & Mikrovaskular & 55 \\
6 & Ny.A & Paska operasi bedah saraf meningioma & 49 \\
7 & Nn.H & Aneurisma & 44 \\
8 & Ny.M & Neoplasma intrakranial & 47 \\
9 & Tn. M & Mikrovaskular & 63 \\
10 & Tn. P & Mikrovaskular & 58 \\
11 & Tn. T & Mikrovaskular & 60 \\
12 & Tn. R & Mikrovaskular & 61 \\
\hline
\end{tabular}

Hasil penelitian pada Tabel 2 menunjukan penyebab terbanyak parese nervus III, IV, VI sebanyak 58,3\% adalah mikrovaskuler.

Dari 7 penderita dengan etiologi mikrovaskuler, diabetes melitus sebagai faktor risiko terbanyak sebanyak 6 orang dan 1 orang penderita hipertensi. Penyebab lain adalah neoplasma intrakranial sebesar 16,7\%, aneurisma, trauma dan paska operasi bedah saraf 
Insiden dan Etiologi Kelumpuhan Saraf III, IV dan VI yang disertai Diplopia Binokuler di RSUD... Rini Kusumawar Dhany, Yunita Tanjung, Farren Jennel

menigioma memiliki persentase sama yaitu $8,3 \%$.

\section{PEMBAHASAN}

Kelumpuhan nervus abducens VI menyebabkan paresis otot rektus lateral dan diplopia horizontal, adalah jenis kelumpuhan saraf okular yang paling banyak didapatkan. Hal ini disebabkan karena saraf abducens memiliki jalur intrakranial terpanjang dan berjalan di basis cranium yang permukaannya kasar sehingga rentan terhadap penyebab langsung dan tidak langsung. Penting untuk membedakan kelumpuhan gabungan nervus III, IV, VI, dari penyakit orbital atau neuromuskular seperti penyakit mata akibat hipertiroid, myasthenia gravis, dan sindrom myopatik melalui anamnesa, pemeriksan klinis dan laboratorium yang lengkap (Graham and Mohseni, 2019).

Saraf ketiga mempersarafi muskulus rektus superior, levator, rektus inferior, rektus medial, dan oblikus inferior serta parasimpatis muskulus sfingter pupil. Jika ada ptosis lengkap, diplopia tidak akan menjadi keluhan. Ukuran pupil dapat bervariasi dari pupil yang benar-benar melebar hingga yang sedikit lebih besar dari yang lain (Sreedhan and Meron, 2019).

Pada sinus kavernosa, saraf keempat terletak di dinding lateral saraf ketiga di bagian atas dan divisi oftalmik nervus trigeminus di bagian bawahnya. la memasuki orbit melalui celah orbital superior di luar Annulus of Zinn dan kerucut otot. Lesi pada sinus kavernosa dan fisura orbital superior tidak mungkin menyebabkan kelumpuhan saraf keempat. Seperti halnya saraf kranial lainnya, mononeuropati iskemik dapat memengaruhi saraf keempat. Onsetnya biasanya tiba-tiba dan berhubungan dengan nyeri periorbital; diplopia biasanya pulih sepenuhnya dalam 4-6 minggu. Sebagian kecil dari penyebab kelumpuhan saraf keempat adalah tumor, meningitis, dan metastasis tumor (Morillon and Bremnes, 2019).

Neuropati yang melibatkan saraf kranialis ketiga, keempat, atau keenam adalah penyebab neurologis paling umum dari diplopia. Iskemia saraf karena keterlibatan mikrovaskuler adalah penyebab paling sering dari kelumpuhan saraf ketiga atau keenam pada orang dewasa (Cornblath, 2014). Ini adalah mekanisme yang diduga bertanggung jawab atas neuropati kranial diabetik. Parese saraf keempat pada umumnya akibat bawaan atau trauma. Aneurisma arteri posterior dan tumor adalah penyebab yang lebih membahayakan dari kelumpuhan saraf ketiga dan harus dipertimbangkan, terutama jika ada keterlibatan pupil awal. Pada anak-anak, 
ISSN 1978-2071 (Print); ISSN 2580-5967 (Online) Jurnal IImiah Kedokteran Wijaya Kusuma 8(2) : 1-6, September 2019

kelumpuhan saraf ketiga dan keempat yang terisolasi paling sering akibat kelainan bawaan atau trauma (Holmes et al, 1999). Dengan tidak adanya riwayat ini, kelumpuhan saraf ke tiga atau keenam diarahkan pada pemeriksaan tumor. Kelumpuhan saraf keenam pada anak-anak sering dilaporkan akibat infeksi virus (Harder, 2010).

Diplopia vertikal dapat muncul pada penyakit mata tiroid dimana otot rektus inferior yang paling sering terkena, fraktur lantai orbital, parese saraf troklear, lesi supranuklear atau infranuklear. Menurut Lutwak (2011) kelumpuhan saraf abducens adalah penyebab umum diplopia binocular. Jika disebabkan oleh penyakit mikrovaskular akibat diabetes dan atau hipertensi, prognosisnya baik. Satu penelitian melaporkan $87 \%$ pemulihan spontan pada lima bulan dan $95 \%$ pada dua belas bulan. Pasien dengan kelumpuhan saraf kranial yang dihasilkan dari penyakit non-mikrovaskuler, etiologinya termasuk multiple sclerosis, myasthenia gravis, trauma memiliki pemulihan lengkap yang dilaporkan pada satu tahun 62\% (Lutwak, 2011). Menurut Comer (2007) bahwa ada 146 pasien dengan diplopia binokular yang disebabkan parese saraf kranial adalah kelompok terbesar terhitung 98 kasus secara total (67\%). Dari kelompok ini, 45 pasien memiliki kelumpuhan saraf keenam dan satu memiliki bilateral keenam, 37 parese nervus IV, 12 memiliki kelumpuhan saraf III, dan dua pasien parese gabungan nervus III, IV, VI. Pasien dengan kelumpuhan saraf kranial secara klinis terkait dengan diabetes atau hipertensi cenderung pulih secara spontan dalam waktu 5 bulan dan pada awalnya hanya memerlukan pengamatan. Namun, pasien dengan diplopia binokular yang tidak jelas penyakit dasarnya dan mengalami progresivitas harus dicari etiologi yang mendasari dan penatalaksanan yang sesuai (Corner et al, 2007). Subgrup terbesar dari pasien dengan parese saraf kranial terdiri dari mereka dengan diduga penyakit mikrovaskuler karena hipertensi atau diabetes akuntansi untuk 58 dari 98 pasien (59\%). Dari ini, 49 pasien mengalami hipertensi, 26 diabetes mellitus, dan 15 pasien memiliki keduanya. Tanda-tanda dan gejala klinis tidak dapat membedakan mikrovaskuler dari kompresi, oleh karena itu MRI dianjurkan untuk dilakukan pada pasien dengan akut, mononeuropati nervus kranial III, IV dan VI (Tamhankar and Volpe, 2015).

\section{KESIMPULAN}

Penyebab diplopia binokuler terbanyak adalah parese nervus $\mathrm{VI}$ dan diurutan kedua parese nervus III dengan 
Insiden dan Etiologi Kelumpuhan Saraf III, IV dan VI yang disertai Diplopia Binokuler di RSUD... Rini Kusumawar Dhany, Yunita Tanjung, Farren Jennel

etiologi terbanyak akibat mikrovaskuler.

Faktor risiko seperti hipertensi dan diabetes mellitus yang berpengaruh signifikan dalam angka diplopia karena parese N. III, IV dan VI perlu dilakukan pemeriksaan MRI lebih awal sehingga komplikasi dan progresivitas dapat dicegah.

\section{DAFTAR PUSTAKA}

Comer RM, Dawson E, Plant G, Acheson JF, Lee JP, 2007. Causes and outcomes for patients presenting with diplopia to an eye casualty department. Eye (Lond). 21(3):413-8.

Cornblath WT, 2014. Diplopia due to ocular motor cranial neuropathies. Continuum (Minneap Minn). 20: 966-80

Dinkin M, 2014. Diagnostic approach to diplopia. Continuum (Minneap Minn). $20 \quad$ (4 Neuroophthalmology): 942-965

Graham C and Mohseni M, 2019. Abducens Nerve (CN VI) Palsy. In: StatPearls [Internet]. Treasure Island (FL): StatPearls Publishing; Available from:

https://www.ncbi.nlm.nih.gov/bo oks/NBK482177/

Harder N, 2010. Temporal arteritis: an approach to suspected vasculitides. Prim Care. 37(4):757-66

Holmes JM, Mutyala S, Maus TL, Grill R, Hodge DO, Gray DT, 1999. Pediatric third, fourth, and sixth nerve palsies: A population-based study. Am J Ophthalmol. 127:38892

Ilyas S, 2009. Ikhtisar Ilmu Penyakit Mata. Jakarta: Balai Penerbit FKUI Lutwak N, 2011. Binocular Double Vision A Review. American Journal of Clinical Medicine. 8(3): 166-169

Merino P, Fuentes D,Gómez de Liaño P,Ordóñez MA, 2017. Diplopía binocular en un hospital terciario: etiología, diagnóstico y tratamiento. Archivos de la Sociedad Española de Oftalmología. 92(12): 565-570

Morillon P and Bremner F, 2017. Trochlear nerve palsy. $\mathrm{Br} J$ Hosp Med (Lond). 78:C38-C40

Sreedhar A and Menon A. 2019. Understanding and evaluating diplopia. Kerala Journal of Ophthalmology. 31(2): 102-111

Tamhankar MA and Volpe NJ, 2015. Management of acute cranial nerve 3, 4 and 6 palsies role of neuroimaging. Current Opinion in Ophthalmology. 26(6): 464-46 